\title{
Nutritional properties of four marine microalgae for albino rats
}

\author{
C. Herrero ${ }^{1}$, J. Abalde ${ }^{1}$, J. Fabregas ${ }^{2}$
}

1. Laboratorio de Microbiología, Departamento de Biología Celular y Molecular, Facultad de Ciencias, Universidad de La Coruña, Campus de A Zapateira s/n., 15071, La Coruña, Spain

2. Laboratorio de Microbiologia, Departamento de Microbiología y Parasitología, Facultad de Farmacia, Universidad de Santiago de Compostela, 15706, Santiago de Compostela, Spain

Journal of Applied Phycology December 1993, Volume 5, Issue 6, pp 573-580

DOI 10.1007/BF02184636

\section{Abstract}

The nutritive value of the marine microalgaeTetraselmis suecica, Isochrysis galbana, Dunaliella tertiolecta and Chlorella stigmatophora was studied in diets given to rats. Biological assays were carried out in order to determine the Protein Efficiency Ratio (PER) and the Food Conversion Efficiency (FCE). Each dried microalga was fed to weaning Wistar albino rats as the sole protein source at a protein level of $12 \%$. Control rats were given diets containing $12 \%$ casein. Food consumption was similar in all groups. PER values obtained were 1.14 with $\mathrm{T}$. suecica diet, 1.13 with I. galbana diet, 2.07 with $\mathrm{D}$. tertiolecta diet and 1.13 with $\mathrm{C}$. stigmatophora diet (casein, 2.50). FCE values followed a similar pattern. The data showed that the marine microalga $D$. tertiolecta is a source of protein of good quality. Its PER is quite high, compared to vegetable and cereal proteins, and compares favourably with other microbial protein sources, such as yeasts or different freshwater microalgae. Haematological tests showed no significant differences among the groups in haemoglobin levels, red and white blood cell counts, differential count and mean corpuscular volume. Different blood parameters were also determined and a significant decrease in triglycerides levels appeared with all the microalgal diets, whereas a significant decrease in cholesterol appeared in D. tertiolecta and $\mathrm{C}$. stigmatophora diets. 


\section{Introduction}

The increasing demand for proteins has led to growing efforts to intensify the production of protein from conventional and unconventional sources. Microbial proteins (Single Cell Protein - SCP - or Biomass Protein - BMP -) have been considered as a protein source only fairly recently. In the context of SCP production, mass culture of microalgae is 4uile appealing, not only because of the high protein content of the cells, but also because of their ability of utilizing solar energy.

Microalgae provide an efficient means of converting solar energy into biomass. The utilization of microalgae has been encouraged by the high biomass yields with high protein levels observed both in the laboratory and outdoors. Besides their high protein content, micro algae contain water- and lipid-soluble vitamins and other valuable products (Becker, 1986; Borowitzka, 1988a, b; Richmond, 1986).

A variety of different microalgae have been investigated for their use as SCP (Becker \& Venkataraman, 1982; 1984; Becker, 1986; 1988) or for the production of fine chemicals (Borowitzka, 1988a; Richmond, 1986). The species considered for these purposes have been freshwater ones, mainly of the genera Chlorella, Dunaliella, Scenedesmus and Spirulina (Becker, 1988). However, marine microalgal mass culture has been focused on its use in aquaculture systems (De Pauw \& Persoone, 1988), although certain marine micro algae are a potential source of a variety of products (Fabregas \& Herrero, 1985; 1986; 1990; Parkinson, 1987; Abalde et al., 1991; Herrero et al., 1992).

The marine unicellular algae Tetraselmis suecica (Prasinophyceae), Isochrysis galbana (Haptophyceae), Dunaliella tertiolecta and Chlorella stigmatophora (Chlorophyceae) have been suggested as potential sources of SCP and have already been evaluated for their protein quality (Fabregas \& Herrero, 1985). Their composition in minerals and vitamins have also been found to be promising (Fabregas \& Herrero, 1986; 1990). Therefore, they could be used as a potential food or feed or as a dietary supplement for human or animals. The aim of the present study was to carry out short-term feeding tests by weaning albino rats on unialgal diets of $T$ suecica, I. galbana, D. tertiolecta or C. stigmatophora in order to establish their nutritive qualities of these algae. 


\section{Materials and methods}

Four different marine photosynthetic micro algae were used. Tetraselmis suecica (Prasinophyceae), Isochrysis galbana (Haptophyceae), Dunaliella tertiolecta and Chlorella stigmatophora (Chlorophyceae). These microalgae were cultured, harvested and dried as previously reported (Fabregas \& Herrero, 1985). The biochemical composition of the dried biomass of each microalga was determined and has been reported elsewhere (Fabregas \& Herrero, 1985; 1986; 1990).

Animals and diets: Biological assays were carried out to determine the Protein Efficiency Ratio (PER) and the Food Conversion Efficiency (FCE). In the test diets each alga was the sole source of protein at a protein level of $12 \%$. Casein was the protein source in the control diet, also at $12 \%$ level. Taking into account the nutritional requirements of the rats (LASA, 1969) and the composition of each microalga (Fabregas and Herrero, 1985; 1986; 1990), the diets were formulated using a linear programme operated on Hewlett Packard HP9817 Computer. All diets were supplemented with methionine. The remaining nutrient requirements of the rat (fat, fibre, vitamins, minerals) must be given in sufficient amounts. All diets were adjusted to $4 \%$ crude fibre and $8 \%$ oil by appropriate additions of cellulose and olive oil. Since casein is a pure protein, all other components must be added to the control diet (oil, sugar, vitamin and mineral mixtures).

Microalgal biomass for the protein supply was sufficient for the vitamin and mineral requirements of rats, so neither vitamin nor mineral mixtures were added to the experimental diets; the oil and sugar present in the microalgal biomass must be completed by adding olive oil and sucrose in order to adjust the diet to the rat requirements.

Table 1. Composition of experimental diets. Protein, fibre and oil contents were $12 \%, 4 \%$ and $8 \%$, respectively, in all diets. Mineral mixture contained ( $\mathrm{g} \mathrm{kg}^{-1}$ mixture): $\mathrm{NaCl}, 338 ; \mathrm{CaHPO}_{4}, 334 ; \mathrm{KHCO}_{3}, 219.6 ; \mathrm{KH}_{2} \mathrm{PO}_{4}, 72 ; \mathrm{MgCO}_{3}, 38 ; \mathrm{FeSO}_{4}, 9.3 ; \mathrm{MnSO}_{4}$, 1.18; $\mathrm{CuSO}_{4}, 0.16 ; \mathrm{AIK}\left(\mathrm{SO}_{4}\right)_{2}, 0.08 ; \mathrm{CaCl}_{2}, 0.08 ; \mathrm{IK}, 0.04 ; \mathrm{FNa}, 0.008$. Vitaminized starch mixture contained (mg g $\left.\mathrm{g}^{-1} \mathrm{starch}\right):$ thiamine, 1.5, riboflavine, 0.2, niacin, 2.2, pyridoxine, 0.4; calcium panthothenate, 0.3; vitamin A, 6 I.U.; vitamin D, 20 I.U.

\begin{tabular}{|c|c|c|c|c|c|}
\hline Component ( $\mathrm{g} \mathrm{kg}^{-1}$ diet) & $\begin{array}{l}\text { Control } \\
\text { diet }\end{array}$ & $\begin{array}{l}\text { T. suecia } \\
\text { diet }\end{array}$ & $\begin{array}{l}\text { 1. galbana } \\
\text { diet }\end{array}$ & $\begin{array}{l}\text { D. tertiolecta } \\
\text { diet }\end{array}$ & $\begin{array}{l}\text { C. stigmatophora } \\
\text { diet }\end{array}$ \\
\hline Casein $+0.5 \%$ Methionine & 150 & - & - & - & - \\
\hline T. suecia $+0.3 \%$ Methionine & - & 333 & - & - & - \\
\hline I. galbana $+0.3 \%$ Methionine & - & - & 353 & - & - \\
\hline D. tertiolecta $+0.3 \%$ Methionine & - & - & - & 253 & - \\
\hline C. stigmatophora $+0.3 \%$ Methionine & - & - & - & - & 343 \\
\hline Sugar & 40 & 27 & 31 & 38 & 28 \\
\hline Oil & 80 & 67 & 41 & 54 & 76 \\
\hline Mineral mixture & 50 & - & - & - & - \\
\hline Vitamin mixture & 50 & - & - & - & - \\
\hline Starch & 630 & 573 & 575 & 655 & 553 \\
\hline
\end{tabular}


Standard AOAC (1980) procedures were used for protein, crude fibre and oil analysis of the feeds. The compositions of the control and algal diets are shown in Table 1.

Each diet was fed to weaning Wistar albino rats. Female Wistar weaning rats $42-48 \mathrm{~g}$ were randomly divided into five groups of ten. The rats were caged individually, and food and water were given ad libitum. The rats were maintained at $25^{\circ} \mathrm{C}$ and subjected to alternating $12 \mathrm{~h}$ periods of light and darkness. The animals were given the test diets for 4 weeks, and individual body weights were recorded periodically and food consumption measured daily. PER was calculated for each diet as weight gain (g) per unit of protein consumed $(\mathrm{g})$ by the animal. Casein PER is customarily adjusted to an assumed PER of 2.50, which requires a corresponding correction of the experimental values. FCE was calculated as feed consumed $(\mathrm{g})$ per weight gain $(\mathrm{g})$.

At the end of the experimental period, blood was collected by haematological tests, such as haemoglobin content, red and white blood cell counts, differential count and mean corpuscular volume, carried out in a TECHNICON H6000/ H601. The plasma obtained by centrifugation of total blood was analyzed for different parameters (electrotites, cholesterol, triglycerides, enzymes, proteins and others) using an automatic analyzer (HITACHI 737).

After killing the rats, the different organs were removed and relative organ weights ( $g$ organ/ $100 \mathrm{~g}$ body weight) of rats were recorded (Venkataraman et al., 1980).

Statistical analysis of the data were performed using the Mann-Whitney-Wilcoxon nonparametric test.

Table 2. Feed consumption, gain in weight, Protein Efficiency Ratio (PER) and Food Conversion Efficienct (FCE) of rats given diets containing casein and different marine microalgae at a protein level of $12 \%$ for 4 weeks $(n=10)$.

\begin{tabular}{|c|c|c|c|c|c|}
\hline & $\begin{array}{l}\text { Initial weight } \\
\text { (g) }(\bar{x} \pm S D)\end{array}$ & $\begin{array}{l}\text { Gain in weight } \\
\text { (g) }(\bar{x} \pm S D)\end{array}$ & $\begin{array}{l}\text { Feed consumed } \\
\text { (g) }(\bar{x} \pm \mathrm{SD})\end{array}$ & PER $_{\text {corr. }}$ & FCE \\
\hline Casein diet & $44.9 \pm 1.28$ & $94.72 \pm 3.79$ & $274.3 \pm 11.99$ & 2.50 & 2.89 \\
\hline T. suecia diet & $47.4 \pm 3.79$ & $46.18 \pm 5.28$ & $293.6 \pm 23.99$ & 1.14 & 6.35 \\
\hline I. galbana diet & $48.35 \pm 2.16$ & $41.24 \pm 4.19$ & $264.9 \pm 12.99$ & 1.13 & 6.42 \\
\hline D. tertiolecta diet & $42.1 \pm 1.57$ & $82.82 \pm 4.10$ & $289.9 \pm 11.66$ & 2.07 & 3.50 \\
\hline C. stigmatophora diet & $45.27 \pm 1.9$ & $40.51 \pm 5.88$ & $261.6 \pm 20.41$ & 1.13 & 6.45 \\
\hline
\end{tabular}




\section{Results}

The food consumption and the weight gain of the rats during the 4 weeks feeding period are shown in Table 2. There were no significant differences in the food intake among the five groups of rats, whereas the group fed on I. galbana diet showed a significantly higher intake of water than the remaining groups. The weight of the rats did not follow a comparable trend to that of diet consumption (Table 2). Rats fed on casein (control group) showed a weight increase significantly higher than those fed on the different microalgal diets. Among the latter, rats fed on D. tertiolecta had higher weight increase, close to that of the control group.

PER values were similar to weight increase values (Table 2). For a casein PER of 2.50, PER values of the diets with the different marine microalgae were 1.14 for $T$. suecica, 1.13 for $f$. galbana. 2.07 for $D$. tertiolecta and 1.13 for C. stigmatophora. The PER value of $D$. tertiolecta was almost double that of the other microalgae. A similar pattern occurred with the FCE which gave values of 2.89 in the control diet and 3.50 in the $D$. tertiolecta diet, and values above 6 for the remaining diets. The differences between the $D$. tertiolecta and control diets were less than those between the D. tertiolecta and the remaining diets.

Table 3. Relative organ weights ( $\mathrm{g}$ of organ weight $/ 100 \mathrm{~g}$ body weight) of rats fed diets containing $12 \%$ of algal protein or $12 \%$ casein for 4 weeks $(n=10)$. Those marked with asterisk (*) differ significantly from the control $(P<0.01)$.

\begin{tabular}{llllll}
\hline & $\begin{array}{l}\text { Casein } \\
(\bar{x} \pm \mathrm{SD})\end{array}$ & $\begin{array}{l}T . \text { suecica } \\
(\bar{x} \pm \mathrm{SD})\end{array}$ & $\begin{array}{l}\text { I. galbana } \\
(\bar{x} \pm S D)\end{array}$ & $\begin{array}{l}\text { D. tertiolecta } \\
(\bar{x} \pm \mathrm{SD})\end{array}$ & $\begin{array}{l}\text { C. stigmatophora } \\
(\bar{x} \pm \mathrm{SD})\end{array}$ \\
\hline Liver & $5.189 \pm 0.419$ & $4.897 \pm 0.197$ & $5.514 \pm 0.311$ & $5.338 \pm 0.248$ & $4.413 \pm 0.206^{*}$ \\
Kidneys & $1.084 \pm 0.062$ & $1.200 \pm 0.063^{*}$ & $1.147 \pm 0.094$ & $1.051 \pm 0.061$ & $1.196 \pm 0.140$ \\
Heart & $0.477 \pm 0.036$ & $0.438 \pm 0.031^{*}$ & $0.414 \pm 0.033^{*}$ & $0.407 \pm 0.035^{*}$ & $0.459 \pm 0.062$ \\
Lungs & $0.720 \pm 0.044$ & $0.749 \pm 0.069$ & $0.775 \pm 0.060$ & $0.589 \pm 0.043^{*}$ & $0.764 \pm 0.144$ \\
Brain & $1.458 \pm 0.115$ & $1.792 \pm 0.147^{*}$ & $1.405 \pm 0.110$ & $1.358 \pm 0.099$ & $1.640 \pm 0.536$ \\
Spleen & $0.310 \pm 0.030$ & $0.205 \pm 0.021^{*}$ & $0.219 \pm 0.029^{*}$ & $0.227 \pm 0.030^{*}$ & $0.249 \pm 0.023^{*}$ \\
Adrenal gland & $0.026 \pm 0.006$ & $0.032 \pm 0.006$ & $0.032 \pm 0.003$ & $0.026 \pm 0.006$ & $0.029 \pm 0.013$ \\
Thymus & $0.367 \pm 0.087$ & $0.312 \pm 0.043$ & $0.315 \pm 0.072$ & $0.317 \pm 0.070$ & $0.384 \pm 0.046$
\end{tabular}

The absolute weights of the various organs followed the same trend as the body weights, being higher in the control and $D$. tertiolecta group. However, the differences are lower if the relative organ weights ( $\mathrm{g}$ organ weight/ $100 \mathrm{~g}$ body weight) are considered (Table 3). There were differences among the groups in the weights of some of these organs. No significant differences occurred in relative weights of adrenal glands and thymus, whereas the relative weight of the spleen was significantly higher in the control group. Other significant differences respect to the control were: relative liver weight was lower in rats fed on C. stigmatophora; relative kidney weight was higher in rats fed on $T$. suecica; relative heart weight was lower in rats fed on $T$. 
suecica, D. tertiolecta and I. galbana, and the same occurred with the relative weight of lungs in $D$. tertiolecta; relative brain weight was higher in rats fed on $T$. suecica.

There were no haematological abnormalities in any of the groups (Table 4). No significant differences were found among the groups in haemoglobin levels, red blood cell counts, white blood cells counts, relative proportions of the various white cells and mean corpuscular volume.

In the blood parameters analyzed at the end of the experimental period significant differences only occurred in the following cases (Table 5): urea content was significantly higher in rats fed on T. suecica and I. galbana; uric acid and creatinine were significantly higher in rats fed on T. suecica; phosphorus was lower in rats fed on C. stigmatophora; CPK was lower in D. tertiolecta group; triglycerides were lower in all the groups fed on microalgae than in the rats fed on control diet and hypocholesterolemic effects were showed by $D$. tertiolecta and C. stigmatophora.

Table 4. Heamatological data for rats fed diets containing $12 \%$ of algal protein or $12 \%$ casein for 4 weeks $(n=10)$.

\begin{tabular}{lccrrr}
\hline Parameter & Casein & T. suecica & I. galbana & D. teriolecta & C. stigmatophora \\
\hline Haemoglobin $(\mathrm{g} / 100 \mathrm{ml}$ whole blood) & $10.85 \pm 0.85$ & $11.77 \pm 0.85$ & $11.64 \pm 0.88$ & $10.82 \pm 0.88$ & $11.63 \pm 0.55$ \\
Red blood cells $\left(10^{6} / \mathrm{mm}^{3}\right)$ & $3.61 \pm 0.34$ & $3.42 \pm 0.31$ & $3.35 \pm 0.80$ & $3.44 \pm 0.57$ & $3.38 \pm 0.52$ \\
While blood cells $(\mathrm{WBC})$ & & & & \\
Total $\left(10^{3} / \mathrm{mm}^{3}\right.$ ) & $2.40 \pm 0.40$ & $2.47 \pm 0.35$ & $2.79 \pm 0.33$ & $2.12 \pm 0.55$ & $2.46 \pm 0.22$ \\
Lymphcytes $(\%$ of total WBC) & 77.00 & 79.71 & 77.80 & 77.95 & 78.92 \\
Neutrophils $(\%$ of total WBC) & 17.81 & 16.77 & 18.56 & 18.01 & 17.95 \\
Eosinophils $\%$ of total WBC) & 0.70 & 0.26 & 0.50 & 0.25 & 0.37 \\
Monocytes $(\%$ of total WBC) & 1.68 & 1.88 & 1.28 & 1.64 & 1.64 \\
Basophils $(\%$ of total WBC) & 0.40 & 0.30 & 0.54 & 0.78 & 0.50 \\
Mean corpuscular volume $\left(\mu^{3}\right)$ & $62.0 \pm 4.2$ & $65.0 \pm 5.3$ & $63.3 \pm 5.0$ & $64.2 \pm 5.3$ & $60.0 \pm 2.4$
\end{tabular}

Table 5. Blood parameters for rats fed diets containing $12 \%$ of algal protein or $12 \%$ casein for 4 weeks. Those marked with asterisks differ significantly from the control $(P<0.01)$.

\begin{tabular}{|c|c|c|c|c|c|c|}
\hline Variable & (unit) & Casein & T. suecica & I. galbana & D. teriolecta & C. stigmatophora \\
\hline Glucose & $\left(\mathrm{gl}^{-1}\right)$ & 1.40 & 1.31 & 1.44 & 1.35 & 1.32 \\
\hline Urea & $\left(\mathrm{gl}^{-1}\right)$ & 0.18 & $0.30^{*}$ & $0.62^{*}$ & 0.19 & 0.17 \\
\hline Uric acid & $\left(\mathrm{mg} \mathrm{l}^{-1}\right)$ & 10.8 & $26.2^{*}$ & 8.2 & 11.3 & 9.7 \\
\hline Creatinine & $\left(\mathrm{mg} \mathrm{l}^{-1}\right)$ & 3.3 & $4.2^{*}$ & 3.0 & 3.0 & 3.2 \\
\hline $\mathrm{Na}$ & $\left(\mathrm{mEq} \mathrm{I}^{-1}\right)$ & 147 & 148 & 145 & 148 & 147 \\
\hline $\mathrm{K}$ & $\left(\mathrm{mEq} \mathrm{I}^{-1}\right)$ & 4.54 & 4.74 & 3.50 & 5.09 & 3.81 \\
\hline $\mathrm{Cl}$ & $\left(\mathrm{mEq} \mathrm{l}^{-1}\right)$ & 117 & 115 & 116 & 115 & 115 \\
\hline $\mathrm{Ca}$ & $\left(\mathrm{mg} \mathrm{l}^{-1}\right)$ & 88.5 & 91.3 & 82.0 & 85.1 & 93.5 \\
\hline $\mathrm{P}$ & $\left(\mathrm{mg} \mathrm{l}^{-1}\right)$ & 80.8 & 71.1 & 67.3 & 83.1 & $45.5^{*}$ \\
\hline Total protein & $\left(\mathrm{gl}^{-1}\right)$ & 44.3 & 42.3 & 42.7 & 44.3 & 43.4 \\
\hline Albumins & $\left(\mathrm{gl}^{-1}\right)$ & 25.1 & 25.3 & 25.6 & 27.0 & 24.3 \\
\hline Globulins & $\left(\mathrm{gl}^{-1}\right)$ & 19.2 & 17.0 & 17.1 & 17.3 & 19.1 \\
\hline Albumins/globulins & & 1.30 & 1.48 & 1.49 & 1.56 & 1.27 \\
\hline Total bilirrubine & $\left(\mathrm{mg} \mathrm{l}^{-1}\right)$ & 1.0 & 0.5 & $=1.5$ & 1.5 & 2.0 \\
\hline Alkaline phosphatase & (U.I. $\mathrm{I}^{-1}$ ) & 610 & 590 & 649 & 651 & 598 \\
\hline Alalnine aminotransferase & (U.I. $\left.1^{-1}\right)$ & 23.42 & 23.44 & 21.37 & 22.66 & 24.20 \\
\hline Glutamic-oxalacetic transaminase & (U.I. $\left.1^{-1}\right)$ & 17.03 & 16.58 & 18.29 & 17.71 & 16.50 \\
\hline$\gamma$-glutamyl-transpeptidase & (U.I. $1^{-1}$ ) & 0.44 & 0.30 & 0.33 & 0.30 & 0.40 \\
\hline Lactate dehydrogenase & (U.I. $\left.1^{-1}\right)$ & 326 & 367 & 308 & 377 & 366 \\
\hline Creatine phosphokinase & (U.I. $1^{-1}$ ) & 312 & 310 & 321 & $175^{*}$ & 318 \\
\hline Triglycerides & $\left(\mathrm{g}^{-1}\right)$ & 0.69 & $0.49 *$ & $0.16^{*}$ & $0.37^{*}$ & $0.33^{*}$ \\
\hline Cholesterol & $\left(\mathrm{gl}^{-1}\right)$ & 0.86 & 0.90 & 0.80 & $0.69 *$ & $0.71^{*}$ \\
\hline
\end{tabular}




\section{Discussion}

Although data on the chemical composition of the algae give valuable information about their nutritional value, they cannot be considered as a substitute for biological appraisals of protein quality in the animal. PER has been shown to be the most useful test to estimate the nutritive quality of protein $\mathrm{s}$, based on short-term feeding trials with weaning rats, and has been used with most of the microalgae studied as food. Food consumption was similar in all groups; therefore, results of this study cannot be ascribed to decreased food intake during the experimental period. However, food consumption has been reported to be less in some diets with Spirulina and Scenedesmus than in control diets with casein (Becker \& Venkataraman, 1982; Venkataraman, 1983). However, the I. galbana diet provoked an increase in water intake, probably due to the fact that this microalga has the highest ash and chloride content (Fabregas \& Herrero, 1985; 1986).

PER and FCE data (Table 2) show important differences between $D$. tertiolecta and the remaining microalgae assayed. However, data on the chemical composition of these microalgae and on the MEAA index did not show this difference (Fabregas \& Herrero, 1985); this fact encourages the importance of biological tests of protein quality in animals. Table 6 shows the PER values obtained with freshwater micro algae, other microbial proteins and conventional foods, and illustrates the good quality of $D$. tertiolecta protein (Table 2). Its PER value is higher than that found for drum-dried, sundried and freeze-dried Scenedesmus $(1.99,1.14,1.12)$ and lower tan drum-dried Scenedesmus supplemented with methionine (2.20). It is also higher than Chlorella $(0.84,1.89,1.31)$ and Spirulina $(1.78,1.89)$, cereals such as corn (1.23) or wheat (1.21), and close to fish flour (2.33), soybean (2.35) or casein (2.50). The yeasts, probably the microorganisms most used as a protein source (SCP), show a PER value considerably lower than that of $D$. tertiolecta (1.05); this is also lower than those of other freshwater and marine microalgae. PER values between 1.70 and 1.90 are considered as excellent for this type of SCP (Becker, 1980).

As a rule, algal proteins are poorly utilized when intact cells are given to monogastric animals or humans and special treatments are required to disrupt the algal cell wall, thus making the protein accessible to proteolytic enzymes. The effect of various methods for processing and drying the algae on their digestibility has been studied extensively and different processing methods give differences in PER values (Table 6). In the present experiments the marine microalgae were dried in an oven, without using any method to break the cell wall. PER values obtained with T. suecica, I. galbana and 
C. stigmatophora were lower than that reached for D. tertiolecta diets, probably because $D$. tertiolecta lacks a cell wall (Oliveira el al., 1980). PER values obtained with all these marine microalgae were higher than that of un processed Chlorella. Marine microalgae also compare favourably with other protein sources, such as the cereals wheat or corn. PER values of T. suecica, I. galbana and C. stigmatophora were very similar to those of wheat and corn, and the PER value of $D$. tertiolecta was higher than both (Tables 2, 6).

Table 6. Comparative PER values of different protein sources (DD, drum-dried; SD, sun-dried; FD, freeze-dried).

\begin{tabular}{llll}
\hline Protein source & Processing & PER & Reference \\
\hline Casein & & 2.50 & \\
Scenedesmus acutus & DD & 1.99 & Becker et al., 1976 \\
Scenedesmus acutus & SD & 1.14 & Becker et al., 1976 \\
Scenedesmus acutus & FD & 1.12 & Becker et al., 1976 \\
Scenedesmus acutus $+0.3 \%$ Methionine & DD & 2.20 & Becker et al., 1976 \\
Chlorella vulgaris & Raw & 0.84 & Cheeke et al., 1977 \\
Chlorella vulgaris & DD & 1.89 & Thanamunkul et al., 1977 \\
Chlorella vulgaris & Autoclaved & 1.31 & Cheeke et al., 1977 \\
Spirulina & SD & 1.78 & Becker \& Venkataraman, 1984 \\
Spirulina platensis $+0.3 \%$ Methionine & SD & 1.89 & Becker \& Venkataraman, 1984 \\
Wheat & & 1.21 & Venkataraman, 1983 \\
Soybean & & 2.35 & Venkataraman, 1983 \\
Corn & & 1.23 & Becker, 1984 \\
Yeasts & & 1.05 & Venkataraman, 1983 \\
Fish-flour & & 2.33 & Cheeke et al., 1977
\end{tabular}

One of the parameters generally considered in the evaluation of the toxicological effects of microalgal diets is the weight of different organs (Becker, 1980; Payer et al, 1980; Venkataraman et al., 1980; Becker \& Venkataraman, 1982). The relative organ weights of rats fed on the different microalgal diets were normal, although there were some significant differences with respect to the control (Table 3). Differences in relative organ weights also were found in rats fed on diets with freshwater micro algae, especially the organ weights of liver, kidneys, lungs and spleen, although no pathological effects could be observed.

It has been assumed that, since these organs are more metabolic ally active, they will be the most affected by changes in the diet (Payer et a/., 1980). Blood counts indicate no abnormalities in any group (Table 4). Assays with Scenedesmus showed that the density of white blood cells was lower in blood from rats given the algal diets than in that from rats given the control diet of casein, although the differential white blood cell counts and the relative proportions of the various white cells were similar (Venkataraman el al., 1980). In other experiments with this microalga the haemoglobin content in blood from rats given the algal diet was $3 \%$ lower than in that from rats given the casein diet (Payer et al., 1980). None of these differences were observed in the rats given the marine micro algal diets. 
It has been reported that there is an inverse relation between the blood urea content and the biological value of the diet which is sufficiently accurate to provide a useful method for the prediction of protein quality from measurement of urea levels (Eggum, 1970). This is in accordance with the results obtained here for T. suecica, I. galbana and $D$. tertiolecta diets, since rats fed on $D$. tertiolecta showed an urea content similar to casein and a good P ER, whereas rats red on $T$. suecica and I. galbana showed a significantly higher urea content than rats red on casein and a significantly lower PER (Table 5). However, C. stigmatophora did not fit with this rule, because rats fed on it presented a low PER and a normal urea content.

From the different plasma enzymes determined, only CPK values were significantly lower in rats fed on $D$. tertiolecta diets than in rats fed on the control diet, but this enzyme shows very disperse and divergent values and can be strongly altered by physical effort (Wallach, 1979). The remaining enzymes, and the plasma proteins, were similar in all groups. All the groups fed on micro algae showed significantly lower triglycerides levels, and a significant decrease in cholesterol was shown by rats fed on D. tertiolecta and C. stigmatophora. There are numerous reports on the hypocholesterolemic properties of a variety of materials derived from biological sources and foods (Vahouny, 1985) but the hypocholesterolemic properties of microorganisms are less well known. In trials involving the feeding of weaning rats with freshwater microalgae, it was observed that the serum cholesterol levels were lower in animals given the microalgal diets than in controls fed on a casein-based standard diet. This hypocholesterolemic effect increased as the percentage of micro algae in the diet increased (Anusuya- Devi el al., 1979; Rolle \& Pabst, 1980; Venkataraman et al., 1980;

Becker \& Venkataraman, 1982; Anusuya-Devi \& Venkataraman, 1983). This cholesterol lowering property was also previously observed in studies with Dunaliella tertiolecta (Fabregas el al., 1988). High colesterol levels have been correlated with the incidence of coronary diseases and other artherosclerotic lesions, so that the hypocholesterolemic effect of these algal-protein diets can constitute an added advantage.

\section{Acknowledgements}

Thanks are due to Dr J.M. Paz, Hospital General de Galicia, for his interesting comments and excellent technical help in conducting haematological work. The authors also thank the technician B. Fernández-Balboa. 


\section{References}

1. Abalde J, Fabregas J, Herrero C (1991) -Carotene, vitamin C and vitamin E content of the marine microalga Dunaliella tertiolectacultured with different nitrogen sources. Biores. Technol. 38: 121-125.

2. Anusuya Devi M, Venkataramen LV, Rajasekaran T (1979) Hypochoresterolemic effect of diets containing algae on albino rats, Nutr. Rep. Int. 20: 83-90.

3. Anusuya Devi M, Venkataraman LV (1983) Hypochoresterolemic effect of the bluegreen algae Spirulina platensis in albino rats. Nutr. Rep. Int. 28: 519.

4. AOAC (1980) Official Methods of Analysis, 13th edn. Association of Official Agricultural Chemists, Washington, DC.

5. Becker EW (1980) Comparative toxicological studies with algae in India, Thailandia and Perú. In Shelef G, Soccer CJ (eds), Algae Biomass. Production and Use. Elsevier/North Holland Biomedical Press, Amsterdam, 767-786.

6. Becker EW (1986) Nutritional properties of microalgae: potentials and contraints. In Richmond A (ed.), CRC Handbook of Microalgae Mass Culture. CRC Press. Boca Raton, Florida, 339-420.

7. Becker EW (1988) Micro-algae for human and animal consumption. In Borowitzka MA, Borowitzka LJ (eds), Microalgal Biotechnology. Cambridge U.P., Cambridge, 222-256.

8. Becker EW, Venkataraman LV (1982) Biotechnology and Exploitation of Algae- the Indian Approach. Deutsche Gesellschaft für Technische Zusammenarbeit $\mathrm{GmbH}$, Eschborn, F.D.R. 216 pp.

9. Becker EW, Venkataraman LV (1984) Production and utilization of the blue-green alga Spirulina in India. Biomass 4: 105-125.

10. Becker EW, Venkataraman LV, Khanum PM 1976. Effect of different methods of processing on the protein efficiency ratio of the green alga Scenedesmus acutus. Nutr. Rep. Int. 14: 305-314.

11. Borowitzka MA (1988a) Vitamins and fine chemical from micro-algae. In Borowitzka MA, Borowitzka LJ (eds), Micro-algal Biotechnology. Cambridge U.P., Cambridge, 153198.

12. Borowitzka MA (1988b) Fats, oils and hydrocarbons. In M.A. Borowitzka MA, Borowitzka LJ (eds), Micro-algal Biotechnology. Cambridge U.P., Cambridge, 257-287.

13. Cheeke PR, Gasper E, Boersma L, Oldfield JE (1977) Nutritional evaluation with rats of algae (Chlorella) grown on swine manure. Nutr. Rep. Int. 16: 579-585.

14. Eggum, BO (1970) Blood urea measurement as a technique for assessing protein quality. Br. J. Nutr. 24: 983-988.

15. De Pauw N, Persoone G (1988) Micro-algae for aquaculture. In Borowitzka MA, Borowitzka LJ (eds), Micro-algal Biotechnology. Cambridge U.P., Cambridge, 197-221.

16. Fabregas J, Herrero C (1985) Marine microalgae as potential source of single cell protein (SCP). Appl. Microbiol. Biotechnol. 23: 110-113. 
17. Fabregas J, Herrero C (1986) Marine microalgae was potential source of minerals in fish diets. Aquaculture 51: 237-243.

18. Fabregas J, Herrero C (1990) Vitamin content of four marine microalgae. Potential use as source of vitamins in nutrition. J. Ind. Microbiology. 5: 259-264.

19. Fabregas J, Herrero C, Parafita M, Paz JM, Cabezas B, Abalde J (1988) Decrease in plasma cholesterol, triglycerides and CPK levels in rats fed on the marine microalga Dunaliella tertiolecta. Plant. Med. 54: 109-111.

20. Herrero C, Vecino E, Abalde J (1992) The marine microalga Dunaliella tertiolecta (Butcher): Nutritional properties and hypocholesterolemic effects. In Villa TG, Abalde J (eds), Profiles on Biotechnology. Santiago University Press. Santiago de Compostela, 271-288.

21. LASA (1969) Dietary standards for laboratory rats and mice. London: Laboratory Animals Ltd.

22. Oliveira L, Bisalputra T \& Antia NJ (1980) Ultraestructural observation of the surface coat ofDunaliella tertiolecta from staining with cationic dyes and enzymes treatment. New Phytol., 85: 385-392.

23. Parkison $G$ (1987) New techniques may squeze more chemicals from algae. Chem. Eng. 94: 19-22.

24. Payer HD, Pabst W, Runkel KH (1980) Review of the nutritional and toxicological properties of the green alga Scenedesmus obliquus as single cell protein. In Shelef G, Soeder CJ (eds), Algae Biomass. Production and Use. Elsevier/North Holland Biomedical Press, Amsterdam, 787-797.

25. Rolle I, Pabst W (1980) Über die cholesterinsenkende Wirkung der einzelligen Grünalge Scenedesmus acutus 276-3a. I: Wirkung von Walzengetrockneter Algensubsta. Nutr. Metab. 24: 302-313.

26. Richmond A (1986) Microalgae of Economic Potential. In Richmond A (ed.) CRC Handbook of Microalgae Mass Culture. CRC Press. Boca Raton, Florida, 199-244.

27. Thananunkul D, Reungmanipaitoon S, Prasomsup U, Pongjiwanich S, Klafs HJ (1977) The protein quality of algae produced in Thailand as determined by biological assays with rats. Food (IFRPD, Bangkok) 10: 200-209.

28. Vahouny GV (1985) Drugs affecting lipid metabolism. In Kritchevsky D, Holmes WL, Palleti R (eds). Plenum Publishing Corporation VIII: 265-279.

29. Venkataraman LV (1983) Blue-Green AlgaSpirulina. CFTRI Press. Mysore, India, 100 pp.

30. Venkataraman LV, Becker EW, Rajasekaran T, Mathew KR (1980) Investigations on toxicology and safety of algal diets in albino rats. Food and Cosmetics Toxicology 18: 271-275.

31. Wallach MD (1979) Interpretation of Diagnostic Test. A Handbook Synopsis of Laboratory Medicina. Little, Brown \& Company, Boston, 639 pp. 